\title{
Grecka terminologia lowiecka w świetle tekstów prawnych
}

\section{Greek hunting terminology in the aspect of legal texts}

Karolina Gortych-Michalak

\author{
INSTYTUT JĘZYKOZNAWSTWA, UNIWERSYTET IM. ADAMA MICKIEWICZA \\ AL. NIEPODLEGŁOŚCI 4, 61-874 POZNAŃ
}

kmmgortych@gmail.com

\begin{abstract}
The paper presents Greek hunting terminology which exists in standard Modern Greek Language and in normative acts concerning hunting in Greece and in Republic of Cyprus. Both so called hunting language and legal language are languages for special purposes (LSP) and they contain special terminology. It is the most significant criterion to distinguish special language form general language. There is almost an obstacle to unify hunting language and legal hunting language as the discussed legal texts might determine different meaning of the terms when comparing with non-legal hunting language. There is also another obstacle laying in giving different name to the same object by the legislator and by the users of non-legal hunting language. The aim of the paper is to present these differences in the selected example coming from special hunting texts and legal texts (normative acts).
\end{abstract}

Keywords: Hunting, Language for Special/Specific Purposes (LSP), Greek Legal Language, Greek Plain Language.

\section{Wstęp}

Łowiectwo w Grecji i na Cyprze, podobnie, jak w Polsce, to obecnie bardzo wyspecjalizowana działalność społeczna. Jej ekskluzywność wynika z kilku czynników, którymi są, począwszy od najbanalniejszych, brak wiedzy specjalistycznej, czy zasobów finansowych osób zainteresowanych łowiectwem, po przepisy prawne regulujące aktywność łowiecką. Mimo mało powszechnego charakteru łowiectwa, należy podkreślić, iż nie jest to działalność tylko i wyłącznie hobbystyczna, ale działalność, która realnie wpływa na warunki bytowe całych ekosystemów, od których zależą również warunki życia ludzi. $Z$ tego względu jestem zdania, iż wiedza na temat łowiectwa $w$ innych krajach może przyczynić się do współpracy pomiędzy instytucjami prowadzącymi działalność łowiecką na skalę 
międzynarodową, co jest o tyle ważne, że ekosystemy nie ograniczają obszarów swego istnienia do granic państwowych.

Przedmiotem badań niniejszego artykułu jest język specjalistyczny, którym opisuje się działalność łowiecką. Jednak łowiectwo to również sfera życia, która jest przedmiotem regulacji prawnych. Greckie i cypryjskie akty normatywne (ustawy) poświęcone łowiectwu to teksty, w których wykorzystywany jest język specjalistyczny - język łowiecki. Są one też jednak złożonymi wypowiedziami normatywnymi, których funkcją jest stanowienia prawa. Stąd język łowiecki obecny w tekstach ustaw greckich i cypryjskich można uznać za język specjalistyczny z dwóch powodów, którymi są: i) specjalistyczna tematyka i związana $\mathrm{z}$ nim terminologia, ii) funkcja prawotwórcza realizowana $w$ formie skonwencjonalizowanego tekstu aktu normatywnego.

Celem badań jest wskazanie różnic znaczeniowych w obrębie danego terminu oraz różnic w zakresie nazewnictwa jednego pojęcia, jakie są zauważalne $\mathrm{w}$ tekstach specjalistycznych łowieckich oraz $\mathrm{w}$ tekstach prawnych regulujących łowiectwo. Z tego względu na początku artykułu wyjaśnia się pojęcia łowiectwa w Grecji i w Republice Cypru oraz wskazuje definicję języka specjalistycznego. W dalszej kolejności język łowiecki i język łowiecki prawny zostaną przedstawione jako języki specjalistyczne. W drugiej części pracy porównaniu zostaną poddane pojęcia i terminy pochodzące $\mathrm{z}$ tekstów greckich i cypryjskich na temat łowiectwa o charakterze nieprawnym oraz pochodzące z tekstów aktów normatywnych (teksty prawne). Analizie zostaną poddane podstawowe, wybrane pojęcia związane $\mathrm{z}$ łowiectwem.

Stawiana w niniejszym artykule teza to pytanie, czy termin język łowiecki sensu largo może oznaczać również język łowiecki prawny, czy też nie. Wskazane w analizie terminologicznej i pojęciowej różnice i podobieństwa będą stanowić podstawę do odpowiedzi na to pytanie.

\subsection{Starożytne źródla tradycji lowieckiej w Grecji i na Cyprze}

Łowiectwo to obszar aktywności społecznej, która obecnie, podobnie, jak w Polsce, jest regulowana w Grecji i na Cyprze przez prawo. Aktywność ta niegdyś uznawana była w Grecji za rodzaj zajęcia hobbystycznego, ponieważ Grecy, od starożytności nie upatrywali w niej źródła pożywienia, jak inne narody europejskie. Mieszkańcy południowej części Półwyspu Bałkańskiego oraz wysp Morza Jońskiego, Egejskiego i Kreteńskiego żywili się głownie owocami swoich upraw i hodowli (Hammond 1973: 144) Jednocześnie jest to jedna $z$ najstarszych aktywności w dziejach cywilizacji ludzkiej, czego źródła znajdujemy w jednym z najstarszych poematów greckich, w Iliadzie Homera:

A jak biegna, zwierzyny pięknej dostać chciwi,

Za sama lub jeleniem i psy, i myśliwi

On, gdy mu jeszcze zguby zly wyrok nie niesie,

Chowa się między skaty albo w gestym lesie;

Wtem gdy się lew pokaze, krzykiem ich wzbudzony,

Psy i myśliwcy w różne rozpierzchna się strony:

Tak trwożnych pędza Trojan szeregami Grecy, 
Tna mieczami, dzidami przebijaja plecy; ${ }^{1}$

Poematy Homera, Iliada i Odyseja, uznane symbolicznie za początek literatury i kultury greckiej, dostarczają informacji nie tylko potwierdzających fakt parania się łowiectwem przez Greków, ale również informują, iż polowanie polegało na:

i) pogoni za dzikim zwierzem, jak ma to miejsce w księdze 5 lub 10 Iliady, czy w 19 księdze Odysei gdzie epik użył słowa $\eta \theta \dot{\eta} \rho \eta$ oznaczającego gonienie dziczyzny, polowanie (Łazarewicz 1864: 168 i 1865: 121) lub

ii) prowadzeniu psów na polowaniu, byciu myśliwym, jak czyni to postać

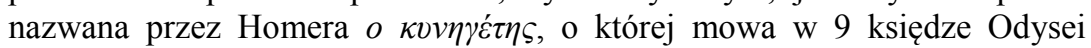
(Łazarewicz 1865: 149).

Iliada jest też źródłem wiedzy na temat Artemidy - pani zwierząt (Kubiak 2003: 236). Ta bogini byłą opiekunką zwierząt i roślin (Pietrzykowski 1983, 120) a sama utożsamiana była z wizerunkiem pięknej, dziewiczej łowczyni, która w krótkiej szacie przemierza góry i lasy w towarzystwie jeleni i psów gończych (Parandowski 1975: 85). W ten sposób Grecy utożsamili łowy z ochroną przyrody, którą uosabiała królowa lasów - Artemida. Koncepcja łowiectwa jako działalności związanej a ochroną fauny i flory przetrwała do epoki współczesnej, w której łowiectwo w Grecji i na Cyprze jest regulowane aktami prawnymi, w których mowa również o ochronie środowiska naturalnego, w tym o ochronie określonych gatunków zwierząt. Takie rozwiązanie legislacyjne ma miejsce na przykład w Republice Cypru, gdzie ustawa

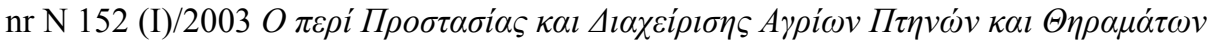
Nónoৎ (Ustawa o ochronie i zarządzaniu zasobami dzikich ptaków i zwierząt) jest źródłem regulacji na temat ochrony środowiska, prowadzenia działalności łowieckiej, organizacji i zasad bezpieczeństwa polowań i analogicznych kwestii.

\subsection{Język specjalistyczny}

Powszechnie uznawane definicje mówią, że język specjalistyczny to narzędzie służące komunikacji specjalistycznej, istniejącej w specjalistycznym środowisku kulturowym, zawodowym itp. Co potwierdza definicja pochodząca ze słownika Longman dictionary of Applied linguistics, gdzie językami specjalistycznymi nazywa się: i) języki wykorzystywane do specjalnych potrzeb (languages for specific purposes/languages for special purposes - languages used for particular and restricted types of communication, (...) and which contain lexical, grammatical, and other linguistic features which are different from ordinary language (Richards i in.1985: 159)) oraz ii) odmiany języka (special languages - a term used for the varieties of language used by specialists in writing about their special matter, such as the language used in botany, law, nuclear physics or linguistics (Richards i in.1985: 264)). Te dwa pojęcia łączą Picht i Draskau (1985: 3) pisząc, że LSP to formalized and codified variety of language, used for special purposes [...] with the function of communicating information of a specialist nature at any level. Komunikacja specjalistyczna bazuje na specjalistycznej terminologii, która jest gromadzona $\mathrm{w}$ formie opracowań encyklopedycznych, leksykonów, czy słowniki terminów z danej dziedziny (Kwary 2011: 63-64). To właśnie terminologia jest podstawową cechą

\footnotetext{
${ }^{1}$ Homer, Iliada, księga XV, wersy 6175-6182 w przekładzie F. Dmochowskiego.
} 
różniącą język specjalistyczny od języka ogólnego, ponieważ za jej pomocą nazywa się zjawiska, przedmioty i postaci właściwe danemu odcinkowi rzeczywistości, jakim jest np. łowiectwo.

\subsection{Grecki język łowiecki i grecki język prawny jako języki specjalistyczne}

Język łowiecki można uznać za język specjalistyczny w świetle przytoczonych powyżej definicji. Język łowiecki może być wykorzystywany do komunikacji pomiędzy podmiotami w obszarze działalności łowieckiej oraz do opisu danego odcinka rzeczywistości, jakim jest aktywność łowiecka.

Grecki język łowiecki nie doczekał się ani specjalistycznego opracowania encyklopedycznego, ani słownikowego sporządzonego w języku nowogreckim, które jest językiem urzędowym w Grecji i w Republice Cypru. Stąd jedynym źródłem greckiej terminologii łowieckiej koniecznej do opisu łowiectwa są słowniki języka greckiego. Należą do nich słownik normatywny języka nowogreckiego wydany przez

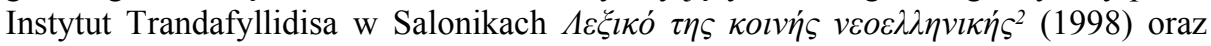

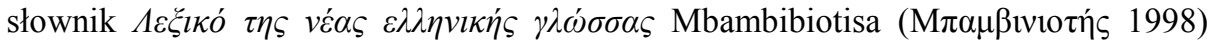
mający charakter mieszany, tj. stanowiący opracowanie słownikowe i encyklopedyczne.

Z drugiej strony łowiectwo jest dziedziną życia społecznego, która jest regulowana przez prawo. Język specjalistyczny, jakim jest język prawny ${ }^{3}$, nie stanowi systemu językowego odrębnego od języka etnicznego, w prawie, bowiem, stosuje się terminologie prawa (prawna i prawnicza) będaca szczególnym rodzajem języka specjalistycznego wewnątrz języka narodowego (Pieńkos 1999: 8). Jest on wariantem języka etnicznego zasadzającym się na systemie języka powszechnego i spełniającym określone zadania. W przypadku języka prawnego, głównym jego zadaniem jest formułowanie prawa, co potwierdza Sandrini pisząc: Law is communication, law is language (Sandrini 2009: 41). Z tego względu do opisu działalności społecznej jaką jest łowiectwo wykorzystuje się odmiany specjalistyczne języka greckiego, jakimi są język łowiecki i język łowiecki prawny.

\section{Terminologia lowiecka}

W prezentowanej analizie źródłem terminologii na temat łowiectwa jest język etniczny, a dokładnie język nowogrecki. Analizie zostanie poddana terminologia w zakresie głównych podmiotów, przedmiotów i czynności związanych z łowiectwem. Zgodnie $\mathrm{z}$ podanymi powyżej źródłami terminologia pochodzi $\mathrm{z}$ i) języka wykorzystywanego do opisu łowiectwa oraz komunikacji w środowisku łowieckim,

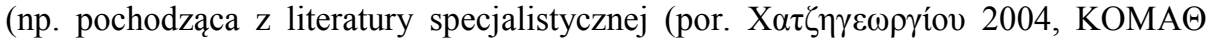

\footnotetext{
${ }^{2}$ Zwany dalej w skrócie Stownik Trandafyllidisa.

${ }^{3}$ Termin język prawny przyjęty za terminem Bronisław Wróblewskiego (Wróblewski 1948).
} 
2011), czy materiałów informacyjnych i edukacyjnych greckich i cypryjskich kół łowieckich) oraz z ii) ustawy regulujących działalność łowiecką w Grecji: $O$ Nó

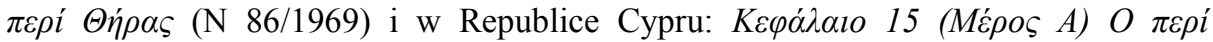

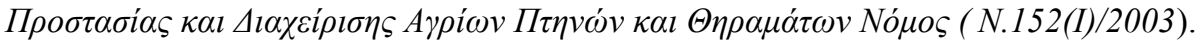

Ponieważ stawianą tezą jest pytanie, czy język prawny regulujący działalność łowiecką można uznać za język łowiecki (rozumiany jako język specjalistyczny sensu largo), terminologia nieprawna $\mathrm{i}$ prawna zostaną zestawione $\mathrm{z}$ punktu widzenia pojęcia, które może mieć różne terminy oraz z punktu widzenia terminu, który może mieć wiele znaczeń.

\subsection{Analiza terminologii lowieckiej w tekstach specjalistycznych i w tekstach prawnych}

Analiza terminologiczna i pojęciowa zostanie przeprowadzona na terminach oznaczających w języku polskim: łowiectwo, polowanie, polować, zwierzyna łowna. W pierwszej kolejności wskazane zostaną znaczenia terminów w oparciu o słowniki języka nowogreckiego a w dalszej kolejności znaczenia, jakie wynikają dla danego terminu $\mathrm{z}$ analizy przywołanych tekstów ustaw obowiązujących w Grecji i w Republice Cypru.

\subsubsection{Termin towiectwo/polowanie}

W języku greckim wykorzystywanym na potrzeby opisu rzeczywistości łowieckiej i komunikacji łowieckiej istnieją dwa terminy oznaczające łowiectwo, z czego termin

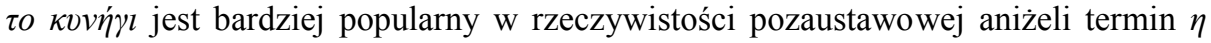
$\theta \dot{\eta} \rho \alpha$. Zarówno słownik Triandafyllidisa jak i słownik Babiniotisa przy definiendum $\eta$ $\theta \eta \dot{\eta} \rho \alpha$ element definicji słownikowej - definiens podaje następującą informację: $(\lambda o \gamma$.)

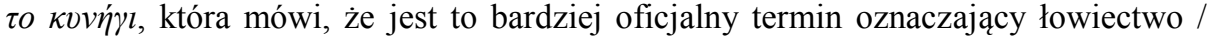
polowanie. $\mathrm{W}$ tekstach nieprawnych poświęconych np. edukacji łowieckiej termin $\eta$

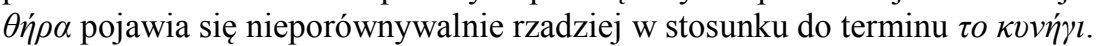

Tymczasem termin $\tau o \kappa v v \eta ́ \gamma l$, do którego odsyła wcześniejsza definicja,

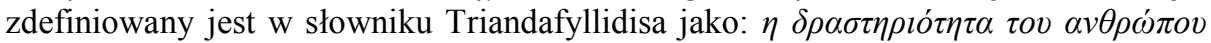

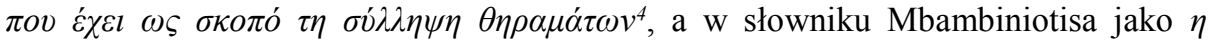

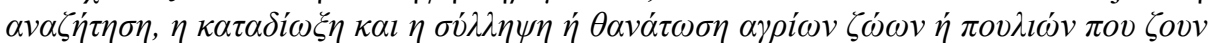

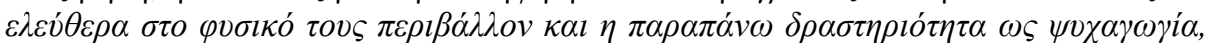
$\chi o ́ \mu \pi l^{5}$.

${ }^{4}$ Działalność człowieka mająca na celu schwytanie zwierzyny. (tłumaczenie autorki, podobnie, jak każde tłumaczenie tekstu z języka greckiego na język polski w niniejszym artykule).

${ }^{5}$ Śledzenie, tropienie i chwytanie lub uśmiercanie dzikich zwierząt lub ptaków, które żyją na wolności w swoim naturalnym środowisku oraz taka działalność uprawiana w charakterze sportowym, jako hobby. 
Z kolei teksty prawne, a dokładnie teksty ustaw, które regulują działalność łowiecką dostarczają informacji, z których można zbudować następującą definicję terminu towiectwo:

a) Grecka ustawa o łowiectwie [O Nó

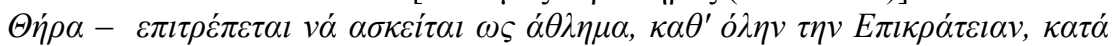

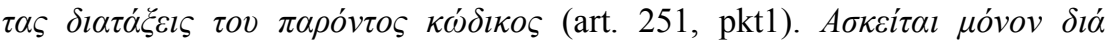

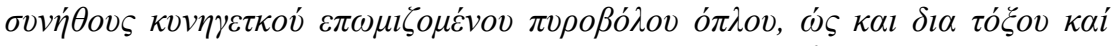

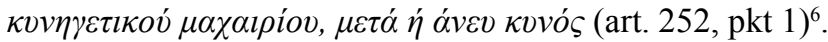

b) Cypryjska ustawa o ochronie i zarządzaniu dzikim ptactwem i zwierzyną

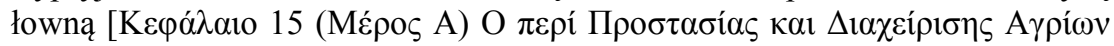

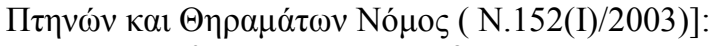

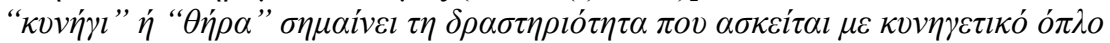

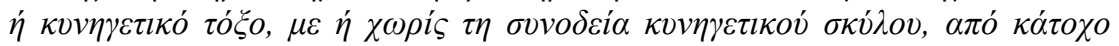
$\dot{\alpha} \delta \varepsilon l \alpha \varsigma \kappa v v \eta \gamma\left\llcorner o v ́(\text { art. } 2)^{7}\right.$

Przytoczone przepisy prawne wskazują, ze język prawny doprecyzowuje znaczenie terminu lowiectwo, poprzez wskazanie rodzaju tej działalności (sport), obszaru, na jakim może być prowadzona oraz sposobu i narzędzi z użyciem których jest prowadzona. W tym świetle język prawny służący opisaniu rzeczywistości łowieckiej proponuje znaczenia hiponimiczne terminu towiectwo w stosunku do języka wykorzystywanego do opisu łowiectwa poza obrotem prawnym. Mimo to znaczenie terminu, wyinterpretowane z przywoływanych tekstów prawnych nie są sprzeczne z pojęciami hiperonimicznymi pochodzącymi z języka łowieckiego nieprawnego.

$\mathrm{Na}$ uwage zasługuje użycie dwóch synonimów terminu towiectwo w ustawie cypryjskiej: $\kappa v v \dot{\eta} \gamma l$ lub $\theta \dot{\eta} \rho \alpha$, podczas, gdy w grackim tekście prawnym termin $\kappa v v \dot{\eta} \gamma l$ nie pojawia się w ogóle. Cypryjski legislator uznaje zatem, że terminy te można stosować wymiennie, jednak analiza całego tekstu ustawy pokazuje, że rzeczownik $\kappa v v \eta ́ \gamma$ pojawia się we frazach $\mathrm{w}$ połączeniu $\mathrm{z}$ innymi rzeczownikami tworząc następujace wyrażenia:

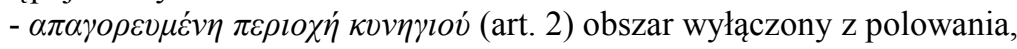

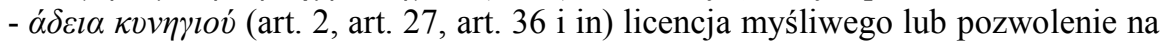
wykonanie polowania,

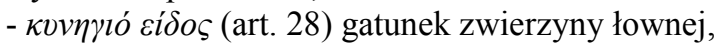

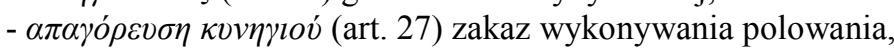

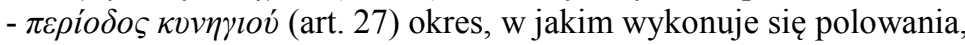

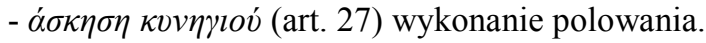

Z powyższej analizy wynika zatem, że w cypryjskim prawnym języku myśliwskim termin $\kappa v v \eta \dot{\gamma}$ jest pojęciem o większym polu semantycznym i oznacza również polowanie, łowy, myślistwo. Tymczasem grecki legislator nie wykorzystuje tego rzeczownika $\mathrm{w}$ ogóle, natomiast $\mathrm{w}$ greckich tekstach prawnych występuje przymiotnik mający tę sama etymologię, co podany powyżej rzeczownik będący

${ }^{6}$ Łowiectwo - dozwala się na uprawianie łowiectwa jako sportu na obszarze całego państwa, zgodnie z przepisami niniejszego kodeksu (art. 251, pkt 1). Łowiectwo jest uprawiane zazwyczaj z użyciem przeznaczonej do tego broni palnej, jak również z użyciem łuku i noża myśliwskiego $z$ wykorzystaniem psów myśliwskich lub bez (art. 252 pkt. 1)

${ }^{7}$ Łowiectwo oznacza działalność, jaka jest prowadzona $\mathrm{z}$ użyciem broni myśliwskiej lub łuku myśliwskiego, z wykorzystaniem lub bez psów myśliwskich, przez posiadacza licencji myśliwego (art. 2). 


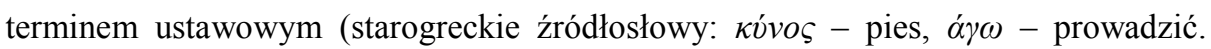

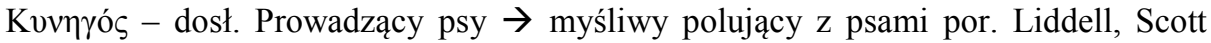

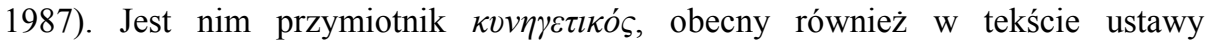

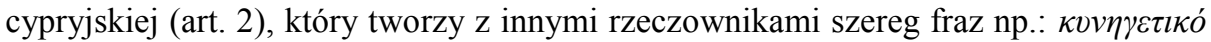

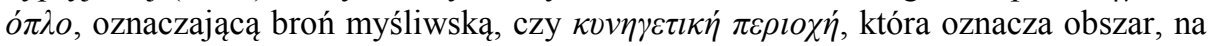
którym wykonuje się polowanie.

Uwagi te prowadzą do wniosku, że grecki i cypryjski prawny język łowiecki dostarczają różnych, niekiedy wymiennych terminów dla pojęcia łowiectwo. Istnieją

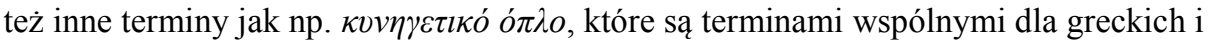
cypryjskich tekstów ustaw, które regulują działalność łowiecką. W tym świetle język łowiecki nieprawny dostarcza pojęć i terminów, które pomagają zrozumieć prawny język łowiecki.

\subsubsection{Termin zwierzyna (lowna)}

Do denotacji zwierzyny łownej z języku opisującym rzeczywistość łowiecką wykorzystuje się w języku greckim termin $\tau o$ $\theta \dot{\eta} \rho \alpha \mu \alpha$. Słowniki i opracowania

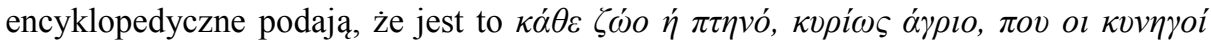

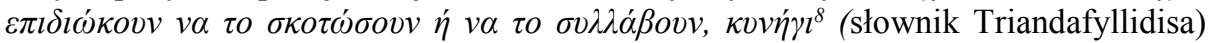

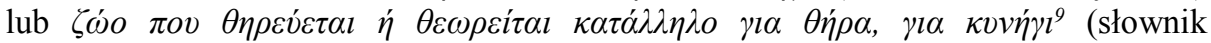
Mbambiniotisa). $Z$ definicji terminu wynika, że alternatywnym synonimem terminu $\theta \dot{\eta} \rho \alpha \mu \alpha$ jest termin $\kappa v v \eta ́ \gamma l$, który w słownikach definiowany jest jako łowiectwo (por. pkt. 2.1.1), ale w dalszej kolejności podaje się również definicję mówiącą, iż jest to ogół zwierząt, populacja, która może być wybita w danym sezonie łowieckim.

Tymczasem w tekstach prawnych znajdują się następujące pojęcia, które definiują termin zwierzyna (towna):

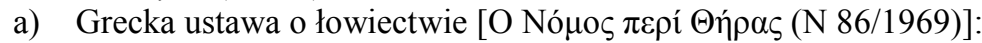

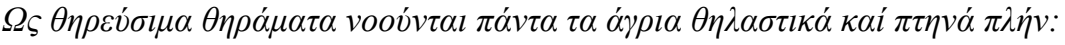

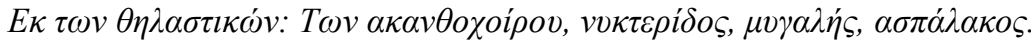

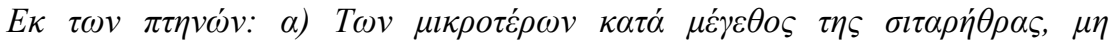

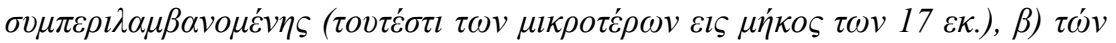

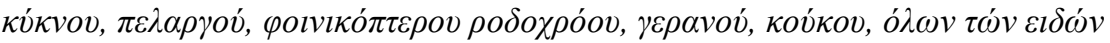

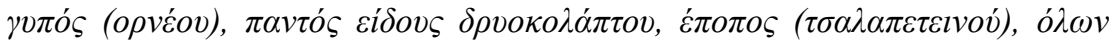

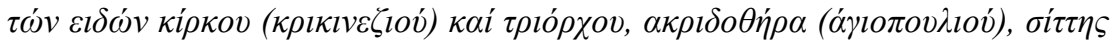

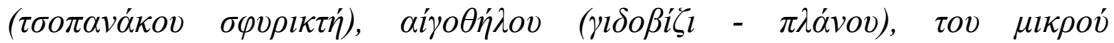

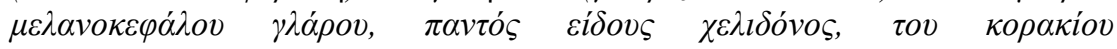

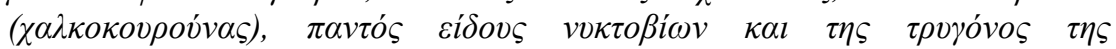

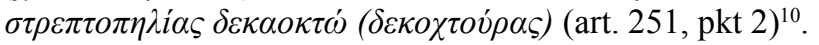

${ }^{8}$ Każde zwierzę lub ptak, zwykle dzikie, za którym myśliwi podążają w celu zabicia lub schwytania go.

${ }^{9}$ Zwierzę, na które się poluje lub zwierzę, które uważa się za odpowiednie do łowienia, do polowania na nie.

10 Jako zwierzynę łowną rozumie się wszystkie ssaki i ptaki z wyłączeniem: Spośród ssaków: jeża, nietoperza, ryjówki, kreta. Spośród ptaków: a) mniejszych pod względem wielkości 
b) Cypryjska ustawa o ochronie i zarządzaniu dzikim ptactwem i zwierzyną

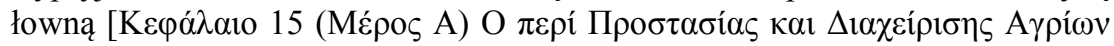

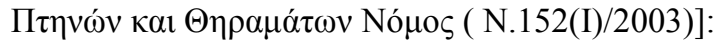

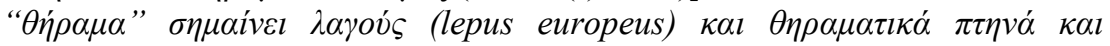

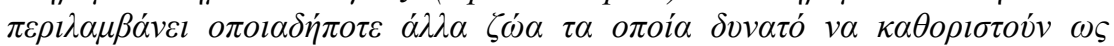

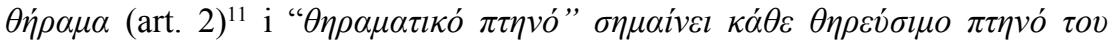

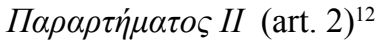

Wskazane pojęcia i terminy pochodzące odpowiednio z ustawy greckiej i cypryjskiej wskazuję, że pojęcie zwierzyny łownej jest hiponimiczne w stosunku do pojęć, jakie zawiera język łowiecki wykorzystywany do opisu działalności łowieckiej. Definicje terminu ustawowego zawężają pojęcie do określonych gatunków zwierząt i ptaków, które mogą być wskazane dokładnie w tekście ustawy, jak ma to miejsce w przypadku greckiego tekstu prawnego lub w załączniku do danej ustawy, jak wynika $\mathrm{z}$ tekstu ustawy cypryjskiej. Jednocześnie teksty aktów normatywnych dostarczają informacji, również $\mathrm{w}$ dalszych przepisach, mówiących, że definicja może ulec zmianie w zależności od decyzji podejmowanych przez kompetentne organy władzy państwowej i lokalnej.

Jest to sytuacja analogiczna sytuacji opisanej w przypadku terminu towiectwo, powyżej. Można zatem wysunąć wniosek, iż język specjalistyczny, jakim jest język, którym opisuje się daną rzeczywistość (tu dokładnie działalność łowiecką), kiedy jest wykorzystany również $\mathrm{w}$ określonej funkcji (w analizowanym przypadku funkcją to jest tworzenie prawa), dostarcza terminów, których znaczenie jest zawężone na potrzeby realizacji danej funkcji języka.

\section{Wnioski}

Przeprowadzona w niniejszym artykule analiza wybranych, podstawowych pojęć z zakresu łowiectwa stanowi prolegomena do dalszych badań nad językiem łowieckim jako językiem specjalistycznym, Zaproponowane przeze mnie dualistyczne rozumienie terminu języka specjalistycznego, czyli języka zawierającego terminologie konieczną do opisu danego odcinak rzeczywistości oraz języka, który spełnia określone funkcje, wskazuje, iż badania nad językiem specjalistycznym prowadzone dwutorowo, dostarczają dokładniejszych informacja w porównaniu $\mathrm{z}$ badaniem przeprowadzonym na podstawie jednego kryterium, np. kryterium zależności języka specjalistycznego w stosunku do języka etnicznego.

skowronków z wyłączeniem (mniejszych niż te, które mają wysokość niższą niż $17 \mathrm{~cm}$ )., b) łabędzi, bocianów, flamingów różowych, żurawi, kukułek, wszystkich gatunków sępa, wszystkich gatunków dzięcioła, dudka, wszystkich gatunków pustułeczki i sokoła, pasterza, szpaka azjatyckiego, lelka zwyczajnego, mewy czarnogłowej małej, wszystkich gatunków hirundo, kraski, wszystkich gatunków sów i turkawki oraz sierpówki.

11 Zwierzyna oznacza zająca szaraka (lepus europeus) oraz ptactwo łowne oraz obejmuje wszelkie inne zwierzęta, które mogą być uznane za zwierzynę łowną (art. 2).

12 Ptactwo łowne oznacza każdego ptaka, na jakiego można polować, o jakim mowa w załączniku II do niniejszej ustawy (art. 2). 
W świetle przedstawionych obserwacji uważam, że dalszym etapem badan jest analogiczna analiza innych terminów charakterystycznych dla języka łowieckiego. Badania pojęć i terminów tego języka specjalistycznego można również przeprowadzić w oparciu o kryterium innych funkcji języka, jak np. komunikacja językowa pomiędzy użytkownikami danego języka specjalistycznego. W taki sposób można wyłonić szereg odmian socjolektów, których suma tworzy język łowiecki będący językiem specjalistycznym rozumianym jako wariant języka etnicznego wykorzystywany do celów specjalistycznych (LSP).

\section{Bibliografia}

1. Hammond, N. G. L.: Dzieje Grecji. Państwowy Instytut Wydawniczy, Warszawa (1973)

2. Homer: Iliada. w przekł. Franciszka Ksawerego Dmochowskiego; zrewidował, wstępem i koment. opatrzył Tadeusz Sinko. Krakowska Spółka Wydawnicza, Kraków (1924)

3. Kubiak, Z. Mitologia Greków i Rzymian. Świat Książki, Warszawa (2003)

4. Kwary, D., A.: Towards a typology of definitions for LSP diCtionaries. [w:] Journal of English Studies. Vol 9 (red.). Pilar Agustín Llach s. 55-73. Universidad de La Rioja, La Rioja (2011)

5. Liddell, H., G., Scott, R.: A lexicon abridged from Liddell and Scott's Greek-English lexicon. The Clarendon Press. Oxford (1987)

6. Łazarewicz, B.: Słownik do Homera i Iliady i przypisywanéj mu Batrachomyomachii / ułożył Łazarewicz. Nakładem i drukiem Ludwika Merzbacha, Poznań (1864)

7. Łazarewicz, B.: Słownik do Homera Odyssei / ułożył Łazarewicz. Księgarnia Jana Konstantego Żupańskiego, Poznań (1865)

8. Parandowski, J.: Mitologia. Czytelnik, Warszawa (1975)

9. Picht, H., Draskau, J. Terminology: An introduction. University of Surrey, Guildford (1985)

10. Pieńkos, J.: Podstawy juryslingwistyki. Język w prawie - prawo w języku. Muza SA, Warszawa (1999)

11. Pietrzykowski, M.: Mitologia starożytnej Grecji. Wydawnictwa Artystyczne i Filmowe, Warszawa (1985)

12. Richards, J., C., Platt J., Talbot, W., H.: Longman dictionary of applied linguistics. Longman, Harlow, Essex (1985)

13. Sandrini, P.: The Parameters of Multilingual Legal Communication in a Globalized World. Comparative Legilinguistics. International Journal for Legal Communication. Vol 1/2009. red. Bańczerowski J. s. 34-48. Instytut Jezykoznawswta, Uniwersytet im. Adama Mickiewicza w Poznaniu, Poznań (2009)

14. Wróblewski, B.: Język prawny i prawniczy. Nakład Polskiej Akademii Umiejętności, Kraków (1948)

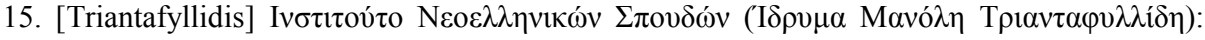

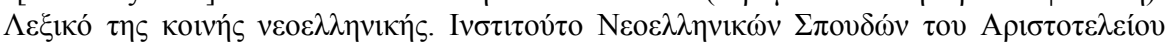

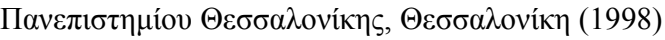

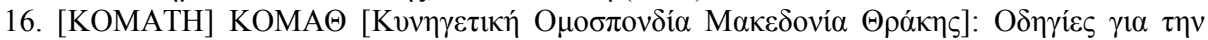

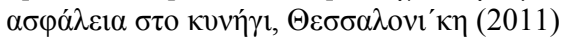

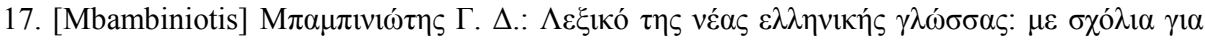

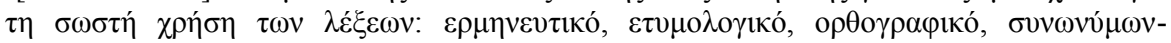

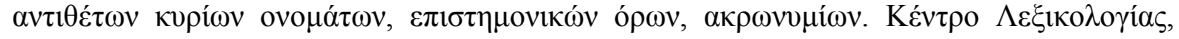
AӨńva (1998) 


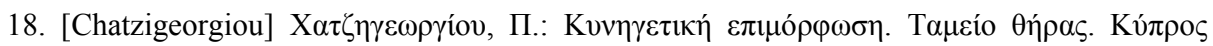
(2004)

\section{Przywoływane akty prawne}

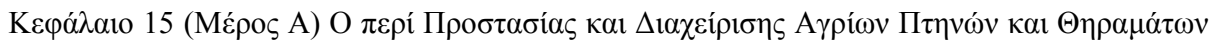
Nónos ( N.152(I)/2003).

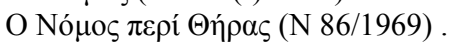

